\title{
Human Fetal Erythrocyte and Plasma Lipids*
}

\author{
James Crowley, $\dagger$ Peter Ways, $\$$ and John W. Jones \\ (From the Department of Medicine, University of Washington School of Medicine, \\ Seattle, Wash.)
}

The human fetal erythrocyte differs in several important respects from its adult counterpart: it is larger (1-3), contains predominantly hemoglobin F (4), has a shorter life span (5), and, of greatest biologic importance, is able to attract and carry maximal oxygen loads at a lower oxygen pressure $\left(\mathrm{PO}_{2}\right)$ than the adult cell $(6-8)$. Surprisingly, the last of these differences is not explained by the presence of hemoglobin $\mathrm{F}$ since its affinity for $\mathrm{O}_{2}$ is the same as that of hemoglobin A when both are in solution (7-10).

These and other differences between fetal and adult erythrocytes suggest differences in the structure and permeability of the respective membranes. Since virtually all of human erythrocyte lipids are in the hemoglobin free ghost (and, therefore, presumably the membrane) $(11,12)$, it seemed important to determine whether the lipid composition of fetal cells differs from that of adult erythrocytes. The lipids of adult erythrocytes have been fractionated, quantified, and characterized in several recent studies (13-17) employing more adequate extraction procedures and more precise chromatographic and analytic techniques than previously available.

In prior studies on fetal erythrocytes, the amounts of cholesterol $(18,19)$ and phospholipid (18-20) have been measured, but reports on phospholipid distribution are few and have differed (19-21). To our knowledge, adequate characterization of cord erythrocyte lipids has

* Submitted for publication December 28, 1964 ; accepted February 25, 1965.

This investigation was supported by funds from the American Heart Association, provided in part by the Washington State Heart Association, and by U. S. Public Health Service grants HE 07326 and AM HD 08864-01.

$\dagger$ Medical student research trainee supported in part by U. S. Public Health Service grant 5T 5GN 2208.

$\ddagger$ Established Investigator, American Heart Association. Address requests for reprints to Dr. Peter Ways, Dept. of Medicine, University of Washington School of Medicine, Seattle, Wash. 98105. not been reported, and data on their fatty acid composition are meager (22). This study was designed to acquire a more complete knowledge of fetal erythrocyte lipids and to compare them with their adult counterparts. Because the erythrocyte phospholipid distribution and fatty acid composition exhibited differences from those in adult erythrocytes, fetal plasma phospholipids were also investigated and found to differ from adult plasma in a qualitatively similar fashion. Portions of this work have been reported in abstract form (23).

\section{Methods}

Subjects. All cord blood was obtained at the end of term pregnancies. Delivery was uncomplicated and by the vaginal route. The infants appeared normal at birth and weighed between 3,200 and 4,200 $\mathrm{g}$.

Blood sampling and extraction. Blood was drawn from the umbilical vein immediately after delivery of the placenta ( 5 to 15 minutes after delivery of the infant), using EDTA (1 $\mathrm{mg}$ per $\mathrm{ml}$ of blood) as an anticoagulant. After centrifugation of the blood at $4^{\circ} \mathrm{C}$, the buffy coat and plasma were removed and the cells washed three times with $0.9 \% \mathrm{NaCl}$ ( $\mathrm{pH}$ adjusted to 7.4 by addition of sodium bicarbonate). After resuspension of the cells in $0.9 \% \mathrm{NaCl}$ to a hematocrit of 31 to $58 \%$, the suspension was mixed well, and samples were removed for hematocrit, electronic erythrocyte counting, and lipid extraction.

Erythrocyte lipids were extracted by procedure III of Ways and Hanahan (17). Plasma lipids were extracted as follows : $\mathrm{N} \mathrm{ml}$ of plasma was added dropwise to $10 \mathrm{~N}$ $\mathrm{ml}$ of methanol with stirring. After the mixture had stood 10 minutes at room temperature, $20 \mathrm{~N} \mathrm{ml}$ of chloroform was added, with mixing. After 20 minutes, the solution was filtered through Whatman 1 filter paper and the residue re-extracted three times with $5 \mathrm{~N} \mathrm{ml}$ of chloroform: methanol, $2: 1$, and filtered. $10 \mathrm{~N} \mathrm{ml}$ of $0.1 \mathrm{M}$ $\mathrm{KCL}$ was added to the combined filtrates. The material was then shaken and cooled to $4^{\circ} \mathrm{C}$. Upon rewarming to room temperature, two phases separated cleanly, and the lower portion was collected, dried under vacuum at 27 to $37^{\circ}$, and taken to volume in benzene.

All extractions and analyses were done in duplicate. Twelve individual and three pooled samples (containing blood from five to seven individual cord samples) of fetal erythrocytes were analyzed. Eleven individual and two 
pooled samples (containing five and six individual samples) of fetal plasma were examined.

Chromatography of lipids. The techniques of silicic acid column and paper chromatography, thin-layer chromatography, and gas-liquid chromatography have been described (17). Preparation of the silicic acid impregnated paper was modified as follows from the method previously described. After four rinses in water, the papers were rinsed an additional time in $\frac{1}{4} \%$ disodium EDTA. When dry, the paper was stored under room conditions until needed and then heated 1 to $1 \frac{1}{2}$ hours at $100^{\circ}$ immediately before chromatography. ${ }^{1}$ The chromatograms were developed in an ascending system utilizing diisobutylketone, $N$-butyl ether, acetic acid, and water $-20 / 20 / 20 / 2.5$ to 3 ( vol/vol) as solvents (14). While this system consistently separated ethanolamine glycerophosphatides, serine glycerophosphatides, choline glycerophosphatides (lecithin), sphingomyelin, and lysolecithin, the inositol glycerophosphatides usually ran at the lower margin of the sphingomyelin spot. ${ }^{2}$ When such chromatograms were eluted for quantitative determination of the phospholipids (14), inositol glycerophosphatides and sphingomyelin were eluted together.

To establish definitively the relative percentage of sphingomyelin, two procedures were employed. First, two pools of fetal erythrocyte lipid were chromatographed on silicic acid columns (17). This separated inositol glycerophosphatides completely from sphingomyelin. Subsequently these separated fractions were chromatographed on silicic acid paper, and the percentage of sphingomyelin could then be determined (14). Secondly, aluminum oxide chromatography was used to separate the acidic phospholipids from the choline-containing phospholipids (24). The absorbant aluminum oxide (suitable for chromatography) ${ }^{3}$ was washed five times with chloroform: methanol $1: 1$ ( $\mathrm{vol} / \mathrm{vol}$ ) (C:M 1/1) in a beaker, the supernatant containing finely divided $\mathrm{Al}_{2} \mathrm{O}_{3}$ being decanted each time. One $\mathrm{g}$ of $\mathrm{Al}_{2} \mathrm{O}_{3}$ was used for each $0.5 \mathrm{mg}$ lipid phosphorus. The column was packed in $\mathrm{C}: \mathrm{M} 1 / 1$. After applying the sample in $C: M 1 / 1$, Fraction I was eluted with $15 \mathrm{ml}$ of $\mathrm{C}: \mathrm{M} 1 / 1$ for each $0.5 \mathrm{mg}$ of lipid phosphorus and was shown by thin-layer and paper chromatography to contain only neutral lipid, sphingomyelin, choline glycerophosphatide, lysolecithin, and on one oc--

\footnotetext{
1 These modifications were suggested by Dr. Claude F. Reed, Rochester, N. Y.

${ }^{2}$ Nomenclature: Present chromatographic methods give rise to fractions characterized by a single base but containing diacyl, vinyl ether, and saturated ether derivatives of glycerophosphate. The term ethanolamine glycerophosphatides refers to such a chromatographic fraction based on ethanolamine, which is known to contain ethanolamine diacyl glycerophosphatide (phosphatidyl ethanolamine) and may or may not prove, later in the investigation, to contain the corresponding plasmalogen (phosphatidyl ethanolamine) and/or glyceryl ether derivative(s). Corresponding terms are used for serine-, inositol-, and choline-derivative mixtures.
}

3 Merck \& Co., Rahway, N. J. casion, small quantities of serine glycerophosphatides. Fraction II, eluted with ethanol : chloroform : water $5: 2: 2$, contained ethanolamine glycerophosphatides, serine glycerophosphatides, and inositol glycerophosphatides; no choline-containing lipids were detectable with the phosphomolybdic acid stannous chloride reaction. When this fraction was chromatographed on thin-layer plates, no spots with the mobility of choline glycerophosphatide or sphingomyelin were seen. Fraction I was rechromatographed on silicic acid impregnated paper, and the relative amounts of sphingomyelin and choline glycerophosphatide were determined by quantitative elution of lipid phosphorus (14).

Analytical methods. The procedures used for the analysis of lipid phosphorus, cholesterol, total weight, fatty acid esters, nitrogen, plasmalogens, and phospholipid fatty acids have been previously described (17).

\section{Results}

1) Analysis of total fetal erythrocyte lipid. Although fetal and adult erythrocytes are comparable in total lipid, phospholipid, and cholesterol content per $\mathrm{ml}$ of packed cells (Table I), the larger fetal red cells contain more of each lipid component per cell. The proportion of total lipid unaccounted for by lipid phosphorus and cholesterol is higher in fetal than in adult cells.

2) Phospholipid distribution. The phospholipid distribution of fetal erythrocytes determined by paper chromatography of the total lipid extract is shown in Table II. The proportion of choline glycerophosphatides is less, and that of sphingomyelin plus inositol glycerophosphatides more, than in adult cells. In four of the ten analyses, the sphingomyelin and inositol glycerophosphatides were $2 \%$ or more in excess of the choline glycerophosphatide value. In the adult determinations, on the other hand, the sphingomyelin and inositol glycerophosphatide percentage was always at least $2.0 \%$ less than the choline glycerophosphatide value, and in four of the seven analyses was at least $4 \%$ less. Analysis of these results utilizing the $t$ test (25) shows the differences in sphingomyelin plus inositoglycerophosphatides to be significant $(p<0.001)$, and the differences in choline glycerophosphatides less so ( $p 0.01$ to 0.02 ). An additional pooled sample in which ethanolamine glycerophosphatides and serine glycerophosphatides were not separated gave similar results: sphingomyelin plus inositol glycerophosphatide, $30.1 \%$; choline 
TABLE I

Composition of total erythrocyte lipids

\begin{tabular}{|c|c|c|c|c|c|c|}
\hline \multirow[b]{3}{*}{$\begin{array}{l}\text { Total lipid per ml cells }(\mathrm{mg}) \\
\text { per cell }\left(10^{-10} \mathrm{mg}\right)\end{array}$} & \multicolumn{3}{|c|}{ Adult* } & \multicolumn{3}{|c|}{ Fetal } \\
\hline & \multirow{2}{*}{$\begin{array}{r}\text { No. } \\
9 \\
9\end{array}$} & \multirow{2}{*}{$\begin{array}{c}\text { Mean } \\
4.88 \\
4.88\end{array}$} & Range & \multirow{2}{*}{$\begin{array}{l}\text { No. } \\
10 \\
10\end{array}$} & \multirow{2}{*}{$\begin{array}{l}\text { Mean } \\
5.06 \\
6.14\end{array}$} & Range \\
\hline & & & $\begin{array}{l}4.60-5.30 \\
4.60-5.30\end{array}$ & & & $\begin{array}{l}4.70-5.55 \\
5.71-6.93\end{array}$ \\
\hline $\begin{array}{l}\text { Lipid phosphorus per } \mathrm{ml} \text { cells }(\mathrm{mg}) \\
\text { per cell }\left(10^{-10} \mathrm{mg}\right)\end{array}$ & $\begin{array}{l}18 \\
18\end{array}$ & $\begin{array}{l}0.127 \\
0.127\end{array}$ & $\begin{array}{l}0.120-0.135 \\
0.120-0.135\end{array}$ & $\begin{array}{l}10 \\
10\end{array}$ & $\begin{array}{l}0.115 \\
0.141\end{array}$ & $\begin{array}{l}0.106-0.126 \\
0.133-0.148\end{array}$ \\
\hline $\begin{array}{l}\text { Cholesterol per ml cells }(\mathrm{mg}) \\
\text { per cell }\left(10^{-10} \mathrm{mg}\right)\end{array}$ & $\begin{array}{l}16 \\
16\end{array}$ & $\begin{array}{l}1.26 \\
1.26\end{array}$ & $\begin{array}{l}1.12-1.45 \\
1.12-1.45\end{array}$ & $\begin{array}{l}11 \\
11\end{array}$ & $\begin{array}{l}1.23 \\
1.50\end{array}$ & $\begin{array}{l}1.17-1.32 \\
1.42-1.58\end{array}$ \\
\hline $\begin{array}{l}\text { As per cent total lipid } \\
\text { Lipid phosphorus } \\
\text { Cholesterol }\end{array}$ & & $\begin{array}{l}2.60 \\
25.8\end{array}$ & & & $\begin{array}{l}2.28 \\
24.5\end{array}$ & \\
\hline
\end{tabular}

* The adult erythrocyte values are from Ways and Hanahan (17); since the average mean corpuscular volume of washed adult erythrocytes was 100 , there were $10^{10}$ cells per $\mathrm{ml}$ of packed erythrocytes.

glycerophosphatide, $24.0 \%$; serine glycerophosphatide plus ethanolamine glycerophosphatide, $36.9 \%$; phosphatilic acid, $6.2 \%$; lysolecithin and unidentified lipid phosphorus, $2.8 \%$. Total recovery of lipid phosphorus in this experiment was $97.8 \%$.

To ascertain whether these findings indicated an increase in sphingomyelin or in inositol glycerophosphatides, or in both, two pooled and one individual sample of fetal erythrocyte lipid were chromatographed on silicic acid columns. The fractions eluted with $\mathrm{C}: \mathrm{M} 1 / 1$ contained serine glycerophosphatides and virtually all of the inositol glycerophosphatides. By rechromatographing this fraction on paper, the amount of inositol glycerophosphatide as per cent of total phospholipid was determined. It measured 2.6, 2.3, and $1.9 \%$ in the three experiments. The weighted average of these three experiments, $2.4 \%$, is not significantly higher than the value of $2.2 \%$ found by identical column chromatographic procedures for adult erythrocytes (17). When these values for inositol glycerophosphatides are subtracted from the respective sphingomyelin plus inositol glycerophosphatide percentages (Table II), the corrected sphingomyelin figure of $26.5 \%$ in fetal cells remains higher than the value of $23.1 \%$ for adult cells. It is also higher than the previously reported figure of $23.8 \%$ for adult erythrocyte sphingomyelin obtained by combined column and paper chromatography of adult erythrocyte lipids (17).

Additional evidence that the sphingomyelin/ choline glycerophosphatide ratio is higher in fetal cells was obtained by chromatographing four additional samples of fetal erythrocyte lipid on aluminum oxide (Table III). This procedure separated the choline-containing phospholipids from the rest of the phospholipids including phosphatidyl inositol (see Methods). In the four

TABLE II

Percentage distribution of erythrocyte phospholipids as determined by paper chromatography

\begin{tabular}{|c|c|c|c|c|c|}
\hline & \multicolumn{2}{|c|}{ Adult* } & \multicolumn{2}{|c|}{ Fetalt } & \multirow{2}{*}{ p value } \\
\hline & Mean & SD & Mean & $\mathrm{SD}$ & \\
\hline Choline glycerophosphatides & 29.9 & 1.72 & 27.6 & 1.62 & $0.01-0.02$ \\
\hline $\begin{array}{l}\text { Sphingomyelin plus inositol } \\
\text { glycerophosphatides } \\
\text { Ethanolamine glycerophosphatides } \\
\text { Serine glycerophosphatides } \\
\text { Other } \\
\text { Recovered }\end{array}$ & $\begin{array}{r}25.3 \\
24.7 \\
14.8 \\
5.4 \\
99.0\end{array}$ & $\begin{array}{l}1.85 \\
1.65 \\
0.82 \\
2.3\end{array}$ & $\begin{array}{r}28.9 \\
22.2 \\
15.2 \\
6.1 \\
101.0\end{array}$ & $\begin{array}{l}1.22 \\
1.42 \\
1.69 \\
3.48\end{array}$ & $\begin{array}{l}<0.001 \\
0.01-0.001 \\
\text { NS }\end{array}$ \\
\hline
\end{tabular}

* Seven individual samples.

† Eight individual and two pooled samples. 
TABLE III

Percentage distribution of choline glycerophosphatides (CGP) and sphingomyelin as determined by column chromatography

\begin{tabular}{|c|c|c|c|c|}
\hline & \multicolumn{2}{|c|}{ CGP } & \multicolumn{2}{|c|}{ Sphingomyelin } \\
\hline & Mean & SD & Mean & SD \\
\hline \multicolumn{5}{|l|}{ Fetal } \\
\hline \multirow{2}{*}{$\begin{array}{l}\mathrm{Al}_{2} \mathrm{O}_{3} \text { chromatography } \\
\text { (4 individual samples) } \\
\text { Silicic acid chromatography } \\
\text { (1 individual sample) }\end{array}$} & 27.8 & \multirow{2}{*}{1.75} & 26.2 & \multirow{2}{*}{1.24} \\
\hline & 27.8 & & 26.2 & \\
\hline \multicolumn{5}{|l|}{ Adult } \\
\hline $\begin{array}{l}\text { Silicic acid chromatography } \\
\text { (reference 17) }\end{array}$ & 29.5 & 1.20 & 23.8 & 1.30 \\
\hline p value & \multicolumn{2}{|c|}{$0.05-0.10$} & \multicolumn{2}{|c|}{$<0.01$} \\
\hline
\end{tabular}

experiments, recovery of lipid phosphorus in Fraction I ranged from 53.3 to $66.8 \%$, and except for small amounts of serine glycerophosphatides in one experiment, there were no other phospholipids except choline glycerophosphatides, sphingomyelin, and traces of lysolecithin present by paper or thin-layer chromatography. When Fraction I was rechromatographed on silicic acid paper, a true sphingomyelin: choline glycerophosphatide relationship could be obtained. The average percentage of sphingomyelin was again higher and the percentage of choline glycerophosphatide lower in the fetal than in the adult cells. In an additional individual sample, all of the phospho- lipids were quantified by combined silicic acid column and paper chromatography with identical results (Table III). In these experiments the difference in sphingomyelin was statistically significant $(p<0.01)$; the difference in choline glycerophosphatides nearly so ( $\mathrm{p} 0.05$ to $0.1 ; t=$ 1.97).

Although the data (Table II) also suggest that the ethanolamine phosphoglycerides may be lower in the fetal than in the adult cells, the notorious lability of this compound $(15,26)$ limits interpretation of this finding. Serine glycerophosphatides constitute a similar fraction of the total in both adult and fetal cells.

3) Characterization of fetal erythrocyte phospholipids. Two pooled samples of fetal erythrocyte phospholipids were separated by silicic acid column chromatography into four major (B, C, $D, E)$ and three minor $\left(A, B^{\prime}, D^{\prime}\right)$ fractions that were partially characterized. The analyses from one of these separations are given in Table IV. Ninety-one per cent of the lipid phosphorus was recovered from the column. Fraction A contained $1 \%$ of the total lipid phosphorus. Paper and thin-layer chromatography revealed phosphatidic acid and serine glycerophosphatides. Gasliquid chromatography of fatty acids was not done. Fraction B was predominately ethanol-

TABLE IV

Analytical and chromatographic data on fetal erythrocyte phospholipid fractions*

\begin{tabular}{|c|c|c|c|c|c|c|c|}
\hline Fraction & $\mathbf{A}$ & B & B & $\mathrm{C}$ & $\mathrm{D}$ & $\mathrm{D}$ & $\mathrm{E}$ \\
\hline Major component & & EGP & EGP, SGP & SGP & CGP & CGP, SP & SP \\
\hline Minor component & & SGP & IGP & IGP & & & \\
\hline $\begin{array}{l}\text { Phosphorus, per cent of total } \\
\text { recovered }\end{array}$ & 1.0 & 29.8 & 1.1 & 15.5 & 21.1 & 13.0 & 17.6 \\
\hline Phosphorus, per cent of total weight & & 3.72 & & 2.34 & 3.60 & & 3.48 \\
\hline Fatty acid ester/P molar ratio & 3.36 & 1.36 & & 1.74 & 1.80 & 0.79 & 0.124 \\
\hline Plasmalogen/P molar ratio & & 0.42 & & 0.025 & 0.035 & & \\
\hline \multicolumn{8}{|l|}{ Paper and thin-layer chromatography } \\
\hline Major components & PA, SGP & EGP & EGP, SGP & IGP, SGP & CGP & CGP, SP & SP \\
\hline Minor components & Unknown & SGP & & EGP & & & \\
\hline Major nitrogen base after hydrolysis & & $\begin{array}{l}\text { Ethanol- } \\
\text { amine }\end{array}$ & & Serine & Choline & & Choline \\
\hline Anthrone reaction & Positive & $\begin{array}{l}\text { Strongly } \\
\text { positive }\end{array}$ & & Positive & Trace & Trace & Trace \\
\hline
\end{tabular}

* Abbreviations: EGP = ethanolamine glycerophosphatide; SGP = serine glycerophosphatide; IGP = inositol glycerophosphatide; $\mathrm{CGP}=$ choline glycerophosphatide; $\mathrm{SP}=$ sphingomyelin; $\mathrm{PA}=$ phosphatidic acid; and $\mathrm{P}=$ phosphorus. 
TABLE V

Fatty acid distribution of fetal erythrocyte total phospholipid (moles/100 moles fatty acid)

\begin{tabular}{cccc}
\hline & & \multicolumn{2}{c}{ Fetal } \\
\cline { 3 - 4 } $\begin{array}{c}\text { Fatty acids } \\
\text { as methyl } \\
\text { esters }\end{array}$ & $\begin{array}{c}\text { Adult } \\
\text { (refer- } \\
\text { ence 17) }\end{array}$ & $\begin{array}{c}\text { Experi- } \\
\text { ment 1 }\end{array}$ & $\begin{array}{c}\text { Experi- } \\
\text { ment 2 }\end{array}$ \\
\hline $14: 0$ & 0.7 & 0.6 & 0.6 \\
$16: 0$ & 24.5 & 24.9 & 25.6 \\
$16: 1$ & 0.2 & 2.5 & 1.5 \\
$18: 0$ & 19.0 & 16.1 & 18.1 \\
$18: 1$ & 16.4 & 13.4 & 13.5 \\
$18: 2$ & 11.2 & 3.4 & 3.5 \\
$18: 3$ & & & Trace \\
$20: 0$ & 1.5 & 0.5 & 0.6 \\
$20: 3$ & 15.1 & 16.4 & 17.1 \\
$20: 4 *$ & 1.6 & 3.9 & 1.3 \\
$22: 4$ & 3.5 & 0.5 & Trace \\
$22: 5$ & 2.5 & 5.4 & 6.0 \\
$22: 6$ & $3.3 \dagger$ & 5.8 & 6.4 \\
$24: 0$ & & 3.2 & 3.3 \\
$24: 1$ & 3.5 & &
\end{tabular}

* On the columns used for these estimations, 22:0 eluted with the same retention time as 20:4. From the hydrogenated samples and the analyses on Apiezon, 22:0 was calculated to be less than $3 \%$ of the total. In the adult it comprises approximately $0.5 \%$ of the total (17).

$\dagger$ These two methyl esters were eluted together with an unsaturated $\mathrm{C}_{22}$ ester that was mixed with one or both peaks. The total values given for $24: 0$ and $24: 1$ include this unsaturated methyl ester.

amine glycerophosphatide but did contain $8.3 \%$ serine glycerophosphatides. Almost half of this fraction contained plasmalogen, representing $91 \%$ of the plasmalogen recovered from the columns. Fraction $\mathrm{C}$ was a complex mixture of polar lipids.
By thin-layer and paper chromatography, the lipid phosphorus in this fraction was found to be $77 \%$ serine glycerophosphatides and $13 \%$ inositol glycerophosphatides. Components that did not contain phosphorus were also identified and were presumed to represent glycolipids. Fraction $\mathrm{D}$ and Fraction $\mathrm{E}$ were virtually pure choline glycerophosphatide and sphingomyelin, respectively.

4) Fatty acid composition of fetal erythrocyte phospholipids. Fatty acids esterified to total erythrocyte phospholipid differ from the adult $(16,17)$ principally in their lower content of linoleic acid (18:2) and higher concentrations of palmitoleic $(16: 1)$, lignoceric $(24: 0)$, and docosahexaenoic $(22: 6)$ acids (Table V). The fatty acids esterified to the individual phospholipid fractions isolated by column chromatography (Table VI) were similar to comparable fractions from adult cells $(16,17)$ except for the lesser amounts of $18: 2$ and the greater amount of $20: 4$ found in Fraction D, the choline glycerophosphatides. Fraction $\mathrm{E}$ (sphingomyelin) differed only in that it contained less 18:2 and 22:0 than the comparable adult fraction.

5) Fetal plasma lipids (Table VII). As shown in previous studies (27-29, earlier investigations reviewed by these authors), cord plasma contains less phospholipid and cholesterol than adult

TABLE VI

Distribution of fatty acids in fetal erythrocyte phospholipid fractions separated by silicic acid chromatography (moles/100 moles of fatty acid)

\begin{tabular}{|c|c|c|c|c|c|c|}
\hline \multirow{2}{*}{$\begin{array}{l}\text { Fatty acids } \\
\text { as methyl } \\
\text { esters }\end{array}$} & \multirow{2}{*}{$\begin{array}{c}\text { Fraction B } \\
\text { Ethanolamine } \\
\text { phospho- } \\
\text { glycerides } \\
\text { Exp. 1 }\end{array}$} & \multirow{2}{*}{$\begin{array}{c}\text { Fraction C } \\
\text { Serine } \\
\text { phospho- } \\
\text { glycerides } \\
\text { Exp. 1 }\end{array}$} & \multicolumn{2}{|c|}{$\begin{array}{c}\text { Fraction D } \\
\text { Choline } \\
\text { phosphoglycerides }\end{array}$} & \multicolumn{2}{|c|}{$\begin{array}{c}\text { Fraction E } \\
\text { Sphingomyelin }\end{array}$} \\
\hline & & & Exp. 1 & Exp. 2 & Exp. 1 & Exp. 2 \\
\hline \multirow{5}{*}{$\begin{array}{l}14: 0 \\
16: 0 \\
16: 1 \\
17: 0 \\
17: 1 \\
18: 0 \\
18: 1 \\
18: 2 \\
20: 0 \\
20: 2 \\
20: 3 \\
20: 4 \\
22: 0 \\
22: 4 \\
22: 5 \\
22: 6 \\
24: 0 \\
24: 1\end{array}$} & $\begin{array}{r}0.3 \\
24.4 \\
2.1\end{array}$ & $\begin{array}{c}0.3 \\
4.9 \\
1.0 \\
\text { Trace }\end{array}$ & $\begin{array}{c}0.6 \\
39.0 \\
1.8 \\
\text { Trace } \\
\text { Trace }\end{array}$ & $\begin{array}{r}0.6 \\
44.0\end{array}$ & $\begin{array}{r}1.2 \\
: 44.9 \\
0.7 \\
0.5\end{array}$ & $\begin{array}{r}0.5 \\
37.5 \\
0.4\end{array}$ \\
\hline & $\begin{array}{r}12.0 \\
18.3 \\
2.5\end{array}$ & $\begin{array}{r}46.4 \\
5.4 \\
1.4\end{array}$ & $\begin{array}{r}10.4 \\
17.5 \\
7.0\end{array}$ & $\begin{array}{r}10.2 \\
18.9 \\
6.7\end{array}$ & $\begin{array}{r}12.9 \\
2.4 \\
0.7 \\
2.8\end{array}$ & $\begin{array}{c}13.6 \\
2.5 \\
\text { Trace } \\
3.4\end{array}$ \\
\hline & $\begin{array}{r}1.2 \\
2.4 \\
20.0\end{array}$ & 0.8 & $\begin{array}{r}3.7 \\
13.8\end{array}$ & $\begin{array}{r}3.1 \\
11.6\end{array}$ & \multirow[b]{2}{*}{$\begin{array}{l}5.5 \\
0.4 \\
1.3\end{array}$} & \multirow[b]{2}{*}{5.6} \\
\hline & 1.9 & $\begin{array}{l}2.6 \\
3.5\end{array}$ & 1.1 & \multirow[b]{2}{*}{3.4} & & \\
\hline & $\begin{array}{l}8.6 \\
6.3\end{array}$ & $\begin{array}{l}7.6 \\
4.3\end{array}$ & $\begin{array}{l}4.0 \\
1.4\end{array}$ & & $\begin{array}{l}14.4 \\
11.9\end{array}$ & $\begin{array}{l}20.1 \\
16.3\end{array}$ \\
\hline
\end{tabular}


TABLE VII

Plasma lipids

\begin{tabular}{|c|c|c|c|c|c|c|c|}
\hline & \multicolumn{3}{|c|}{ Adult } & \multicolumn{3}{|c|}{ Fetal } & \multirow[b]{2}{*}{$\mathrm{p}$ value } \\
\hline & No. & Mean & $\overline{\mathrm{SD}}$ & No. & Mean & $\overline{\mathrm{SD}}$ & \\
\hline Lipid phosphorus $(\mathrm{mg} / 100 \mathrm{ml})$ & 21 & 9.12 & 0.9 & $12^{*}$ & 4.15 & 1.1 & \\
\hline Cholesterol (mg/100 ml) & 19 & 214 & 3.6 & $12^{*}$ & 71.7 & 15.0 & \\
\hline $\begin{array}{l}\text { Phospholipid distribution } \\
\text { (Per cent total lipid phos- } \\
\text { phorus) }\end{array}$ & 7 & & & 8 & & & \\
\hline Lecithin & & 66.7 & 2.4 & & 59.6 & 5.8 & $0.01-0.02$ \\
\hline Sphingomyelin & & 21.4 & 1.9 & & 26.4 & 4.4 & $<0.01$ \\
\hline Other & & 11.9 & 2.9 & & 14.0 & 4.5 & NS \\
\hline Per cent phosphorus recovered & & 99.6 & & & 102 & & \\
\hline
\end{tabular}

* Eleven individual and one pooled sample.

plasma (Table VII). Preliminary ultracentrifugal data indicate that this is due to lower concentrations of both high and low density lipoprotein, but particularly the latter. As in the erythrocyte lipids, sphingomyelin constitutes a greater $(\mathrm{p}<0.01)$ and the choline glycerophosphatides a lower ( $p 0.01$ to 0.02 ) percentage of the total phospholipid than found in adult plasma.

\section{Discussion}

This investigation describes significant differences in the lipid composition of fetal and adult erythrocytes. The larger average amount of total lipid, cholesterol, and phospholipid per fetal erythrocyte correlates well with a greater mean corpuscular volume. The higher proportion of total lipid in fetal cells that is unaccounted for by lipid phosphorus and cholesterol suggests that they may be higher in glycolipid content than adult erythrocytes. Fractionation of the phospholipids has revealed relatively more sphingomyelin, less choline glycerophosphatides, and perhaps less ethanolamine glycerophosphatides in the fetal cell as compared with the adult. Similar, although insignificant differences between adult and 1- to 2-day infant erythrocyte choline glycerophosphatides and sphingomyelin were reported by Bentley (20). In a single sample of cord erythrocyte cells, Phillips (19) also found changes comparable to those we have observed. However, the adult erythrocyte phospholipid distribution reported by these investigators differs from those reported from this laboratory (17) and by Reed, Swisher, Marinetti, and Eden (14), making comparison difficult. Analysis of the fatty acids esterified to total phospholipid in fetal cells reveals much less linoleic acid (18:2) and relatively more palmitoleic $(16: 1)$, lignoceric $(24: 0)$, and docosahexaenoic $(22: 6)$ acids. The fatty acids esterified to individual phospholipid classes reflect the same changes.

In fetal plasma, the quantity of total phospholipid and cholesterol is half or less of that in adult plasma, reflecting correspondingly low total lipoproteins. With the exception of Hadnagy and associates' work (30) electrophoretic studies of cord blood suggest that high and low density plasma lipoproteins are comparably reduced (27$29,31-34)$. However, by analytical ultracentrifugation (35) the low density lipoproteins are reduced to a greater extent ( $\frac{1}{4}$ the adult level) than the high density lipoproteins ( $\frac{1}{4}$ to $\frac{1}{2}$ of adult values). Preliminary ultracentrifugal data from this laboratory are in agreement with the latter observations. ${ }^{4}$ In addition to low total phospholipid in fetal plasma, this study has shown that the phospholipid distribution also differs from adult norms. As in the erythrocytes, the per-

\footnotetext{
4 It has been shown that certain lipophilic stains used in electrophoretic lipoprotein analyses have a greater affinity for triglyceride and cholsterol ester than for other lipids (36). Since the low density lipoproteins contain a significantly higher proportion of both these lipid classes than the high density lipoproteins, the discrepancy between the electrophoretic and ultracentrifugal data may be on this basis.
} 
centage of sphingomyelin was higher and that of the choline glycerophosphatides lower than in adult material. Phillips (19) made similar observations on a single sample of cord blood.

Because of the differences in phospholipid distribution of both cord erythrocytes and plasma from comparable adult material, and because of the wider variation of phospholipid distribution in fetal than in adult plasma, it is pertinent that Boyd and Wilson (37) reported increases of fetal whole blood phospholipid as great as $29 \%$ during the interval (10 to 30 minutes in their series) between delivery of the fetus and separation of the placenta. It would be of interest to ascertain whether these whole blood increments represent changes in plasma rather than erythrocyte lipids and whether the changes were due to an increase of one or more than one of the phospholipids.

It is not unlikely that the changes in fetal plasma and erythrocyte phospholipid distribution may be related. Several studies give direct support to the theory that erythrocyte cholesterol $(38,39)$ and certain phospholipids $(22,40,41)$ exchange with the corresponding plasma lipids. In further support of this concept are the studies of blood lipids in a-beta lipoproteinemia. In this disease, both erythrocyte and plasma phospholipids have more sphingomyelin and less lecithin than in the normal $(19,42)$, and this change in the cell phospholipids is a function of cell age (43), suggesting that the cell lipids are normal until they have been in contact with the abnormally constituted lipids of the plasma. In fetal blood, because plasma and erythrocyte lipids both differ in a similar way from their adult counterparts, it is possible that plasma and erythrocyte phospholipid distribution are also interdependent.

Are the differences in lipid composition of fetal and adult erythrocytes found in this study of functional significance? Previous investigators have found that intact fetal erythrocytes, in whole blood or buffer suspensions, have a greater affinity for oxygen than maternal erythrocytes (6-9). This is not explained by the known differences in physical and chemical properties of hemoglobin $\mathrm{F}$ and hemoglobin A (4), for when solutions of hemoglobin are dialyzed $(7,8,10)$ or buffered $(9,10)$ or evaluated in concentrated solution (8), hemoglobin $F$ has the same or less affinity for oxygen as hemoglobin A. Furthermore, the oxygen affinity of erythrocytes from two adults with hereditary persistence of hemoglobin $\mathrm{F}$ has now been determined $(8,9)$. Despite the presence of $34 \%$ and $70 \%$ fetal hemoglobin, the oxygen dissociation curves were identical to those of normal adult erythrocytes. These studies $(7,8,10)$ also minimize the possibility that dialyzable intracellular components may be of importance in explaining differing oxygen affinity of fetal and adult cells. When erythrocyte metabolic activity and enzymes are inhibited (8), the difference in oxygen affinity of intact fetal and adult cells still persists. Thus, the known differences in certain enzyme activities (44-47) and metabolism $(44,48)$ between adult and fetal cells do not seem to explain the differing oxygen affinities.

The possibility that differences inherent in the "membranes" of the fetal and adult cells may effect a difference in their "permeability" to oxygen has been suggested, and there is some direct support for this hypothesis. Thus, Hořejši and Komárková (49) have demonstrated that factors contained in the membranes of adult erythrocytes alter the oxygen affinity of hemoglobin A solutions. Whether addition of fetal "membranes" to solutions of fetal hemoglobin effects a difference in their oxygen affinity has not been determined, but the $\mathrm{O}_{2}$ dissociation curves of intact fetal cells and solutions of fetal hemoglobin do not differ significantly $(7,8)$.

In addition to these suggestions that its membrane may influence the oxygen affinity of the erythrocyte, other studies report dissimilarities of fetal and adult erythrocytes that imply differences in membrane behavior. Thus, the fetal cell is apparently less resistant to mechanical injury (50), but more resistant to hemolysis at $59^{\circ}$ (51), and hemolysis under acid conditions (52). The fetal erythrocyte also exhibits greater loss of $\mathrm{K}^{+}$and increase of $\mathrm{Na}^{+}$intracellularly during storage at $4^{\circ}$ than its adult counterpart (53).

Nearly a quarter of a century ago Ballentine and Parpart (54) changed the permeability of erythrocytes to ethylene glycol and glycerol by exposing them to pancreatic lipases. As a result they proposed that erythrocyte permeability was 
dependent upon the lipids and proteins in their membranes. This hypothesis has been strengthened by Kögl, De Gier, Mulder, and van Deenen (55) and by De Gier and van Deenen (26), who demonstrated differences in the fatty acid composition and phospholipid distribution of erythrocyte membranes in various mammalian species. These variations could be correlated with the species differences in erythrocyte permeability to ethylene glycol and glycerol previously reported by Jacobs, Glassman, and Parpart (56). It was concluded, therefore, that membrane lipid composition might be an important determinant of membrane permeability $(26,55)$.

In conjunction with the present study, the foregoing observations on oxygen affinity and erythrocyte membrane behavior suggest that certain differences in the physiologic behavior of erythrocytes might be related to differences in the lipid content of their membranes.

\section{Summary}

The lipids of fetal erythrocytes have been fractionated, quantified, and characterized in some detail. The phospholipid distribution of fetal plasma has also been studied. The following principal conclusions can be made:

1) The average fetal erythrocyte contains more cholesterol, total phospholipid, and probably glycolipid than the adult erythrocyte.

2) In fetal erythrocytes and plasma, sphingomyelin constitutes a significantly greater percentage of the total phospholipid than in adult material. Choline glycerophosphatide is correspondingly reduced in the fetal erythrocyte and plasma, but this difference is not as significant statistically.

3) Differences in the phospholipid fatty acid composition of fetal and adult erythrocytes are also present. Most striking of these is a very low level of linoleic acid in the fetal cell.

The possible relationship of these findings to differences in the physiologic behavior of fetal and adult cells is discussed.

\section{References}

1. Horan, M. Studies in anaemia of infancy and childhood: the hemoglobin, red cell count, and packed cell volume of normal English infants during the first year of life. Arch. Dis. Childh. 1950, 25, 110.

2. Smith, Carl H. Blood Diseases of Infancy and Childhood. St. Louis, C. V. Mosby, 1960, p. 29.

3. Guest, G. M., E. W. Brown, and M. Wing. Erythrocytes and hemoglobin of the blood in infancy and childhood. II. Variability in number, size and hemoglobin content of the erythrocytes during the first five years of life. Amer. J. Dis. Child., 1938, $56,529$.

4. Huisman, T. H. J. Abnormal hemoglobins. Clin. chim. Acta 1958, 3, 201.

5. Garby, L., S. Sjölin, and J. C. Vuille. Studies on erythrokinetics in infancy. V. Estimations of the life span of red cells in the newborn. Acta paediat. (Uppsala) 1964, 53, 165.

6. Darling, R. C., C. A. Smith, E. Asmussen, and F. M. Cohen. Some properties of human fetal and maternal blood. J. clin. Invest. 1941, 20, 739.

7. McCarthy, E. F. The oxygen affinity of human maternal and foetal haemoglobin. J. Physiol. (Lond.) 1943, 102, 55.

8. Nechtman, C. M., and T. H. J. Huisman. Comparative studies of oxygen equilibria of human adult and cord blood red cell hemolysates and suspensions. Clin. chim. Acta. 1964, 10, 165.

9. Schruefer, J. J. P., C. J. Heller, F. C. Battaglia, and A. E. Hellegers. Independence of whole blood and haemoglobin solution oxygen dissociation curves from haemoglobin type. Nature (Lond.) 1962, 196, 550.

10. Allen, D. W., J. Wyman, Jr., and C. A. Smith. The oxygen equilibrium of fetal and adult human hemoglobin. J. biol. Chem. 1953, 203, 81.

11. Dodge, J. T., C. Mitchell, and D. J. Hanahan. The preparation and chemical characteristics of hemoglobin-free ghosts of human erythrocytes. Arch. Biochem. 1963, 100, 119.

12. Weed, R. I., C. F. Reed, and G. Berg. Is hemoglobin an essential structural component of human erythrocyte membranes? J. clin. Invest. 1963, 42, 581.

13. Phillips, G. B., and N. S. Roome. Phospholipids of human red blood cells. Proc. Soc. exp. Biol. (N. Y.) 1959, 100, 489.

14. Reed, C. F., S. N. Swisher, G. V. Marinetti, and E. G. Eden. Studies of the lipids of the erythrocyte. I. Quantitative analysis of the lipids of normal human red blood cells. J. Lab. clin. Med. 1960, 56, 281.

15. Hanahan, D. J., R. M. Watts, and D. Pappajohn. Some chemical characteristics of the lipids of human and bovine erythrocytes and plasma. J. Lipid Res. 1960, 1, 421.

16. Farquhar, J. W. Human erythrocyte phosphoglycerides. I. Quantification of plasmalogens, fatty acids and fatty aldehydes. Biochim. biophys. Acta (Amst.) 1962, 60, 80. 
17. Ways, P., and D. J. Hanahan. Characterization and quantification of red cell lipids in normal man. J. Lipid Res. 1964, 5, 318.

18. Boyd, E. M. Lipid composition of blood in new-born infants. Amer. J. Dis. Child. 1936, 52, 1319.

19. Phillips, G. B. Quantitative chromatographic analysis of plasma and red blood cell lipids in patients with acanthocytosis. J. Lab. clin. Med. 1962, 59, 357.

20. Bentley, H. P., Jr. Erythrocyte phospholipids in the newborn infant. Proc. Soc. exp. Biol. (N. Y.) 1962, 111, 591.

21. Helmy, F. M., and M. H. Hack. Comparison of the lipids in maternal and cord blood and of human amniotic fluid. Proc. Soc. exp. Biol. (N. Y.) 1962, 110, 91.

22. Farquhar, J. W., and E. H. Ahrens, Jr. Effects of dietary fats on human erythrocyte fatty acid patterns. J. clin. Invest. 1963, 42, 675.

23. Crowley, J., and P. Ways. Fetal red blood cell lipids (abstract). Clin. Res. 1964, 12, 222.

24. Rhodes, D. N., and C. H. Lea. Phospholipids. IV. On the composition of hen's egg phospholopids. Biochem. J. 1957, 65, 526.

25. Fisher, R. A. Statistical Methods for Research Workers. Edinburgh, Oliver and Boyd, 1941, p. 120.

26. De Gier, J. J., and L. L. M. van Deenen. Some lipid characteristics of red cell membranes of various animal species. Biochim. biophys. Acta (Amst.) 1961, 49, 286.

27. Rafstedt, S. Studies on serum lipids and lipoproteins in infancy and childhood. Acta paediat. (Uppsala) 1955, 44 (suppl. 102), 1.

28. Sweeney, M. J., J. N. Etteldorf, W. T. Dobbins, B. Somervill, R. Fischer, and C. Ferrell. Dietary fat and concentrations of lipid in the serum during the first six to eight weeks of life. Pediatrics 1961, 27, 765.

29. Brody, S., and L. A. Carlson. Plasma lipid concentrations in the newborn with special reference to the distribution of the different lipid fractions. Clin. chim. Acta 1962, 7, 694.

30. Hadnagy, C. S., E. A. Lörincz, T. Takács, R. P. Boariu, I. Kifor, A. Erdélyi, I. Pupåzå, and M. Róna. Lipid content of the newborn's blood. Biol. Neonat. (Basel) 1963, 5, 390.

31. Sohar, E., E. J. Bossak, C-I. Wang, and D. Adlersberg. Serum components in the newborn. Science 1956, 123, 461.

32. Brown, D. F., R. B. McGandy, E. Gillie, and J. T. Doyle. Observations on some serum components in mothers and in their newborn infants. Amer. J. Obstet and Gynec. 1959, 77, 556.

33. Chida, N. Paper electrophoretic analysis of serum lipoproteins of normal infants and children. Tohoku J. exp. Med. 1963, 79, 385.

34. Lindquist, B., and R. Malmcrona. Dietary fat in re- lation to serum lipids in the normal infant. Amer. J. Dis. Child. 1960, 99, 39.

35. Auerswald, W., W. Doleschel, and W. Müller-Hartburg. Flotationsanalytische untersuchungen der Lipoproteinverteilung im mütterlichen und im Nabelschnurblut. Klin. Wschr. 1963, 41, 580.

36. Schjeide, O. A., A. U. Rivin, and J. Yoshino. Uptake of lipid stains by lipids and serum lipoproteins. Amer. J. clin. Path. 1963, 39, 329.

37. Boyd, E. M., and K. M. Wilson. The exchange of lipids in the umbilical circulation of birth. J. clin. Invest. 1935, 14, 7.

38. Gould, R. G., G. V. LeRoy, G. T. Okita, J. J. Kabara, P. Keegan, and D. M. Bergenstal. The use of $\mathrm{C}^{14}$-labeled acetate to study cholesterol metabolism in man. J. Lab. clin. Med. 1955, 46, 372.

39. London, I. M., and H. Schwarz. Erythrocyte metabolism. The metabolic behavior of the cholesterol of human erythrocytes. J. clin. Invest. 1953, 32, 1248.

40. Reed, C. F. Studies of in vivo and in vitro exchange of erythrocyte and plasma phospholipids (abstract). J. clin. Invest. 1959, 38, 1032.

41. Polonovski, J., and M. Paysant. Metabolisme phospholipidique du sang. VIII. Ećhange des phospholipides marqués entre globules et plasma sanquin in vitro. Bull. Soc. Chim. biol. (Paris) 1963, 45, 339.

42. Ways, P., C. F. Reed, and D. J. Hanahan. Red-cell and plasma lipids in acanthocytosis. J. clin. Invest. $1963,8,1248$.

43. Ways, P., and D. Dong. Etiology of the RBC phospholipid abnormalities in $\alpha$-beta lipoproteinemia. Clin. Res. 1965, 13.

44. Gross, R. T., E. A. R. Schroeder, and S. A. Brounstein. Energy metabolism in the erythrocytes of premature infants compared to full term newborn infants and adults. Blood 1963, 21, 755.

45. Kaplan, E., and J. T. Tildon. Changes in red cell enzyme activity in relation to red cell survival in infancy. Pediatrics 1963, 32, 371.

46. Gross, R. T., and R. E. Hurwitz. The pentose phosphate pathway in human erythrocytes. Pediatrics 1958, 22, 453.

47. Burman, D. Red cell cholinesterase in infancy and childhood. Arch. Dis. Childh. 1961, 36, 362.

48. Greenwalt, T. J., V. E. Ayers, and S. A. Morell. Phosphate partition in the erythrocytes of normal newborn infants and infants with erythroblastosis fetalis. III. $\mathrm{P}^{32}$ uptake and incorporation. Blood 1962, 19, 468.

49. Hořejší, J., and A. Komárková. The effect of factors contained in the membranes of red blood cells on the shape of the dissociation curve of hemoglobin. Clin. chim. Acta 1959, 4, 391.

50. Bos, S. E. Mechanical fragility of erythrocytes. Maandschr. Kindergeneesk. 1955, 23, 335.

51. Betke, K., and E. Kleihauer. Fetaler und bleibender Blutfarbstoff in Erythrozyten und Erythroblasten 
von menschlichen Feten und Neugeborenen. Blut 1958, 4, 241.

52. Kleihauer, E. Zur Struktur der fetalen Erythrozyten. Wien. Z. inn. Med. 1963, 44, 17.

53. Zipursky, A., T. LaRue, and L. G. Israels. The in vitro metabolism of erythrocytes from newborn infants. Canad. J. Biochem. 1960, 38, 727.

54. Ballentine, R., and A. K. Parpart. The action of lipase on the red cell surface. J. cell. comp. Physiol. 1940, 16, 49-54.
55. Kögl, F., J. De Gier, I. Mulder, and L. L. M. van Deenen. Metabolism and functions of phosphatides. Specific fatty acid composition of the red blood cell membranes. Biochim. biophys. Acta (Amst.) 1960, 43, 95.

56. Jacobs, M. H., H. N. Glassman, and A. K. Parpart. Hemolysis and zoological relationship. Comparative studies with four penetrating non-electrolytes. J. exp. Zool. 1950, 113, 277. 